\title{
Phytotoxicity by Lead as Heavy Metal Focus on Oxidative Stress
}

\author{
Sónia Pinho ${ }^{1}$ and Bruno Ladeiro ${ }^{2}$ \\ ${ }^{1}$ Biology Department, University of Aveiro, 3810-193 Aveiro, Portugal \\ ${ }^{2}$ MAP-BioPlant, Biology Department, Faculty of Science, University of Porto, 4169-007 Porto, Portugal
}

Correspondence should be addressed to Sónia Pinho, sonia.andreia@ua.pt

Received 14 February 2012; Accepted 13 April 2012

Academic Editor: Conceição Santos

Copyright (C) 2012 S. Pinho and B. Ladeiro. This is an open access article distributed under the Creative Commons Attribution License, which permits unrestricted use, distribution, and reproduction in any medium, provided the original work is properly cited.

In the recent years, search for better quality of life in urban areas has been provoking an increase in urban agriculture. However, this new way of agriculture can bring risks to human health since this land is highly contaminated, due to anthropogenic activities. This way, lead $(\mathrm{Pb})$ phytotoxicity approach must be taken into consideration since it can be prejudicial to human health through food chain. $\mathrm{Pb}$ is a common environmental contaminant, which originate numerous disturbances in plant physiological processes due to the bioacummulation of this metal pollutant in plant tissues. This review, focus on the uptake and interaction of lead by plants and how it can be introduced in food chain. Special attention was taken to address the oxidative stress by lead regarding the effects produced in plant physiological and biochemical processes. Furthermore, the antioxidant defence system was taken into consideration. Phytoremediation is applied on site or chronic polluted soils. This emerging technique is useful to bioaccumulate, degrade or decrease risks associated with contaminants in soils, water or air through the use of hyperaccumulaters. In addition, the impact of nanoparticles in plant science was also focused in this article since some improving properties in plants have been increasingly investigated.

\section{General Introduction}

Metals occur naturally in the environment as constituents of the Earth's crust [1]. They tend to accumulate and persist in the ecosystems due to their stability and mainly because they cannot be degraded or destroyed.

Plants absorb numerous elements from soil. Some of the absorbed elements are referred to as essentials because they are required for plants to complete their life cycle. Certain essential transition elements such as iron, manganese, molybdenum, copper, zinc, and nickel are known as micronutrients because they are required by plants in minute quantity [2]. Other transition metals such as silver, gold and cobalt [3, 4], and nontransition elements like aluminum [5] have proven to have a stimulatory effect on plant growth, but are not considered essential. Moreover, it has been documented elsewhere that plants also absorb elements which have no known biological function and are even known to be toxic at low concentrations. Among these are the heavy metals arsenic, cadmium, chromium, mercury, and $\mathrm{Pb}$. However, even micronutrients become toxic for plants when absorbed above certain threshold values [6].

\section{Lead (Pb)}

Lead $(\mathrm{Pb})$ is a silvery-white highly malleable metal. Among his physical properties, at normal environmental conditions this metal is presented in the solid state; it is dense, ductiles, and very soft with poor electrical conductivity when compared to most other metals. The chemical symbol for lead, $\mathrm{Pb}$, is an abbreviation of the Latin word plumbum, meaning soft metal.

$\mathrm{Pb}$ is rarely found in native form in nature but it combines with other elements to form a variety of interesting and beautiful minerals. Galena, which is the dominant $\mathrm{Pb}$ ore mineral, is blue-white in color when first uncovered but tarnishes to dull gray when exposed to air [7].

Archeological research indicates that $\mathrm{Pb}$ has been used by humans for a variety of purposes for more than 5,000 years. In fact, archeological discoveries found glazes on prehistoric ceramics. The Egyptians used grounded $\mathrm{Pb}$ ore as eyeliner with therapeutic proprieties and cosmetic kohl, Pb-based pigments were used as part of yellow, red, and white paint. In ancient Rome- $\mathrm{Pb}$ was used to build pipes for water transportation [7-9]. 
Not so long ago, $\mathrm{Pb}$ had a widespread use in all anthropogenic activities, for instance, leaded paints, automobile batteries (as lead oxide), ammunitions, molten $\mathrm{Pb}$ as coolant, leaded glass, crystal, and fossil fuels. Until recently, tetraethyllead (TEL) was commonly used in petrol fuels as an inexpensive additive used since 1920. TEL was banned in most industrialized countries in the late 1990s to early 2000s due to environmental and health concerns over air and soil pollution (e.g., the areas around roads) and the accumulative neurotoxicity of $\mathrm{Pb}$. This additive compound, however, is still used today in aviation fuel for piston-engine-powered aircraft. Even today $\mathrm{Pb}$ is still used in protective coatings with applications for radiation shielding in medical analysis $[10,11]$.

According to the U.S. Agency for Toxic Substances and Disease Registry, environmental levels of $\mathrm{Pb}$ have increased more than 1,000-fold over the past three centuries as a result of human activity. The greatest increase took place between 1950 and 2000 and reflected the increased use of leaded gasoline worldwide.

$\mathrm{Pb}$ commonly occurs in mineral deposits along with other base metals, such as copper and zinc which have been mined on all continents except Antarctica.

Currently, approximately 240 mines in more than 40 countries produce $\mathrm{Pb}$. World mine production was estimated to be 4.1 million metric tons in 2010, and the leading producers were China, Australia, the United States, and Peru, in descending order of output. In recent years, $\mathrm{Pb}$ was mined domestically in Alaska, Idaho, Missouri, Montana, and Washington. In addition, secondary (recycled) $\mathrm{Pb}$ is a significant portion of the global $\mathrm{Pb}$ supply.

World consumption of refined $\mathrm{Pb}$ was 9.35 million metric tons in 2010. The leading refined $\mathrm{Pb}$ consuming countries were China, the United States, and Germany. Demand for $\mathrm{Pb}$ worldwide is expected to grow largely because of increased consumption in China, which is being driven by growth in the automobile and electric bicycle markets $[12,13]$.

According to Geological Society of America (http://geology.com/usgs/lead/) the worldwide supply and reserves of $\mathrm{Pb}$ are present on Table 1.

\section{3. $\mathrm{Pb}$ in Agriculture and Main Causes of Soil Contamination: The Status in the 21st Century}

Accordingly to an increased number of studies, food crops accumulate trace metals in their tissues when grown on contaminated soil with $\mathrm{Cd}, \mathrm{Pb}$, and $\mathrm{Zn}$ from metal smelting activity, irrigation with wastewater, disposal of solid wastes including sewage sludge, vehicular exhaust, and adjacent industrial activity. Long-term use of these wastewaters on agricultural lands often results in the buildup of elevated levels of heavy metals in soils $[15,16]$.

In addition, in countries with a high demand for food, contaminated arable land is used for crops like rice, cereal grains, and potatoes [6].

Increasing concern on the lack of suitable land for agriculture is prompting urban farmers to use contaminated
Table 1: Pb production and reserves. Data from [14].

\begin{tabular}{lcc}
\hline Country & Production $\left(1000 \mathrm{~m}^{3}\right.$ ton $)$ & Reserves \\
\hline USA & 400 & 7000 \\
Australia & 620 & 27000 \\
Bolivia & 90 & 1600 \\
Canada & 65 & 650 \\
China & 1600 & 13000 \\
India & 95 & 2600 \\
Ireland & 45 & 600 \\
Mexico & 185 & 5600 \\
Peru & 280 & 6000 \\
Poland & 35 & 1500 \\
Russia & 90 & 9200 \\
South africa & 50 & 300 \\
Sweden & 65 & 1100 \\
Other & 330 & 4000 \\
\hline Total & 4100 & 80000 \\
\hline
\end{tabular}

land, such as waste disposal sites, to produce food crops. This situation is exacerbated by rapid population growth, urbanization and industrialization [17]. Thus, urban agriculture, practiced widely in developing countries, can be at great risk due to the proximity of these contaminant sources $[18,19]$.

In urban agriculture, wastewater and solid organic wastes are often the main sources of water and fertilizer used to enhance the yields of stable crops and vegetables. This way, municipal or industrial effluents and solid wastes, often rich in trace metals, contribute significantly to metal loadings in irrigated and waste-amended urban soils. However, studies conducted in soils where the atmospheric deposition was the dominant pathway for $\mathrm{Pb}$ contamination, revealed that the $\mathrm{Pb}$ concentration in those soils decreased with the increasing distance from the road.

Facing the rising population in urban areas, urban agriculture faces problems regarding the balance of the food needs with the potential hazards arising from the use of contaminated urban sites for food production and effluents for irrigation. Previous studies of metal uptake have focused mainly on crop species grown in the developed world and comparatively little information is available concerning vegetables typically grown in periurban environments in developing countries [20].

\section{Edible Vegetables Affected by Pb Contamination}

Many researchers have shown that some common vegetables are capable of accumulating high levels of metals from the soils $[21,22]$.

Studies conducted with edible vegetables species revealed the correlations between the $\mathrm{Pb}$ content in the soils and environment and its effects in vegetables.

Othman [23] reported a direct positive correlation of $\mathrm{Zn}$ and $\mathrm{Pb}$ levels between soils and vegetables. In this study, edible portions of five varieties of green vegetables (collected 
from several areas in Dar Es Salaam, Africa) were analyzed for $\mathrm{Pb}, \mathrm{Cd}, \mathrm{Cr}, \mathrm{Zn}, \mathrm{Ni}$, and $\mathrm{Cu}[16]$.

Tangahu and colleagues [24] demonstrated $\mathrm{Pb}$ accumulation in plant tissues $(\mathrm{mg} / \mathrm{g}$ dry weight) of the roots, shoots, and leaves from different species. They suggested that several plants could accumulate $\mathrm{Pb}$ in their tissues to more than $50 \mathrm{mg} / \mathrm{g}$ dry weight of plant. Among those species are Brassica campestris L, Brassica carinata A. Br., Brassica juncea (L.) Czern, and Brassica nigra (L.) Koch that could accumulate more than $100 \mathrm{mg} \mathrm{Pb} / \mathrm{g}$ dry weight [24]. Also Uwah [22] suggested that certain species of Brassica (cabbage) are hyperaccumulators of heavy metals into their edible tissues.

More studies (De la Rosa et al. [25]) suggested that some wild plants (Prosopis sp. and Salsola kali) edible by humans and/or animals were recently identified as potential hyperaccumulators of $\mathrm{Pb}$ and $\mathrm{Cd}$, respectively.

\section{Pb Uptake by Plants}

As $\mathrm{Pb}$ is not an essential element, plants do not have channels for $\mathrm{Pb}$ uptake. Instead, this element is bound to carboxylic groups of mucilage uronic acids on root surfaces $[26,27]$, but it is still unknown how this element goes into the root tissue. Although some plants species tolerate $\mathrm{Pb}$ through complexation and inactivation (Allium cepa, Hordeum vulgare and Zea mays), other species experience toxicity (Brassica napus and Phaseolus vulgaris) because $\mathrm{Pb}$ hampers some metabolic pathways [28]. In a few plant species, the excess of $\mathrm{Pb}$ inhibits seed germination, plant growth, and chlorophyll synthesis, among other effects [6].

$\mathrm{Pb}$ is considered to have low solubility and availability for plant uptake because it precipitates as phosphates and sulfates, chemicals commonly found in the rhizosphere of plants [29]. Also, $\mathrm{Pb}$ is immobilized in soil when it forms complexes with the organic matter [6].

Several studies have shown that most of the absorbed $\mathrm{Pb}$ remains accumulated in the roots, making the root the first barrier for the $\mathrm{Pb}$ translocation to the above ground plant parts, [29] acting like a natural barrier. Moreover, the increase in accumulation level is directly proportional to the amount of exogenous $\mathrm{Pb}$.

Uptake behavior is known to depend on total soil concentration, soil physico-chemical conditions, and the species and genotypes of the plants involved [30]. Authors have reported the effect of $\mathrm{pH}$ variation in $\mathrm{Pb}$ uptake, in different plant species: in low $\mathrm{pH}$ soils (3.9) an increased mobility of $\mathrm{Pb}$ was observed, resulting in higher uptake. Also, in addition to soil factors and plant species, previous studies have shown that trace metal concentrations may differ between cultivars of individual crop species when grown on the same soil, making the risks associated with contaminated soils, with trace metals, difficult to assess [20].

Once inside the root cortex, $\mathrm{Pb}$ moves in the apoplastic space, using the transpiration conductive system [28, 31]. It can also bypass the endodermis and gain symplastic access in the young root zone and in sites of lateral root initiation [32]. $\mathrm{Pb}$ has been shown to enter and move within the cytoplasm and proteins mediating cross-membrane movement of $\mathrm{Pb}$ have been identified $[33,34]$. Most of the $\mathrm{Pb}$ absorbed by roots is in the form of extracellular precipitate (as phosphate and carbonate) or is bound to ion exchangeable sites in the cell walls [35]. The unbound $\mathrm{Pb}$ is moved through $\mathrm{Ca}$ channels accumulating near the endodermis [36].

Previous experimental results suggest that at low concentration, the Casparian strip of the endodermis is a partial barrier for $\mathrm{Pb}$ movement into the central cylinder tissue [37]. Depending on the plants exposed, different cellular types can be used to store $\mathrm{Pb}$ [36]. Varga et al. [38] found that in roots of wheat, $\mathrm{Pb}$ is fixed to the cell wall but it can be removed as a complex using citric acid, However, Marmiroli [39] reported that in European walnut (Juglans regia), $\mathrm{Pb}$ is retained in the lignocellulosic structure of roots. On the other hand, a small portion can also be translocated upwards to stems, leaves, and probably seeds [6].

Results from the Gardea-Torresdey research group have shown (unpublished data) that in hydroponically grown honey mesquite (Prosopis sp.) associated with Glomus deserticola and treated with high- $\mathrm{Pb}$ concentrations (more than $\left.50 \mathrm{mg} \mathrm{Pb} \mathrm{L}^{-1}\right), \mathrm{Pb}$ concentrates in the phloem tissues, which suggests the $\mathrm{Pb}$ movement through the xylem to leaves, returning through the phloem to the plant body. As described by Cobbett [40], $\mathrm{Pb}$, like other toxic elements, is complexed by the cysteine-rich low molecular weight polypeptides widely known as phytochelatins. However, in Sesbania drummondii $\mathrm{Pb}$ is transported to stems and leaves in structures similar to $\mathrm{Pb}$-acetate, $\mathrm{Pb}$-nitrate, and $\mathrm{Pb}$-sulfide [41]. In addition, López et al. [42, 43] have reported the formation of different $\mathrm{Pb}$ complexes in stems and leaves of alfalfa.

\section{6. $\mathrm{Pb}$ in Food Chain}

According to Ma [44] and Rossato et al. [45] one way of exposure of humans and mammals to $\mathrm{Pb}$ is via the food chain. It has long been recognized that the heavy metal accumulation in soil may result in potential health risk to plants, animals, and humans [46].

Published studies illustrating the transport of $\mathrm{Pb}$ in the food chain are scarce, and further research is needed to establish the role of the plant $\mathrm{Pb}$ compounds in the transference and metabolism of $\mathrm{Pb}$ in the food chain. Other researchers have reported that in humans, two binding polypeptides (thymosin and acyl-coA binding protein) are responsible for the $\mathrm{Pb}$ binding in kidneys [47]. $\mathrm{Pb}$ in blood serum is bound to proteins or complexed with low-molecular-weight compounds such as sulfhydryl groups (e.g., cysteine, homocysteine) and others as citrate, cysteamine, ergothioneine, glutathione, histidine, and oxylate [48].

Lead (II) acetate (also known as sugar of $\mathrm{Pb}$ ) was used by the Roman Empire as a sweetener for wine, and some consider this to be the cause of dementia that affected many of the Roman Emperors [6].

Zhuang and colleagues [46] performed a study where they evaluated heavy metal transfer along a plant-insectchicken food chain on metal contaminated soil. They concluded that chicken fed with insect-larva accumulated significantly high $\mathrm{Pb}$ in the liver, suggesting that the accumulation of heavy metals in specific animal organ should not be 
ignored. In their study they also demonstrated decreases of heavy metals along the soil-plant-insect-chicken food chain. Interestingly, cadmium (Cd) steadily declined with increasing trophic level, but concentrations of zinc $(\mathrm{Zn})$ and copper $(\mathrm{Cu})$ slightly increased from plant to insect larva. An important route to avoid bioaccumulation was the elimination of the four elements in feces of insect and chicken. Metal concentrations in liver, muscle, and blood of chickens were highly variable; however, the highest concentration was in liver and the lowest in blood [46].

Many people could be at risk of adverse health effects from consuming common vegetables cultivated in contaminated soil. The condition of the soil is often unknown or undocumented and therefore, exposure to toxic levels can unconsciously occur [49]. Xu and Thornton [50] suggested the existence of health risks from consuming vegetables with elevated heavy metal concentrations. The populations most affected by heavy metal toxicity are pregnant women or very young children [51]. Low birthweight and severe mental retardation of newborn children have been reported in some cases where the pregnant women ingested toxic amounts of heavy metal through direct or indirect consumption of vegetables [52]. Some of the reported effects of heavy metal poisoning are neurological disorders, central nervous system (CNS) destruction, and cancers of various body organs [16, 48].

Taking the health risks encountered in human diet as a result of high levels of heavy metals in vegetables, agricultural good practices should be implemented. This way, educational and official programs should be implemented and broadcasted to educate farmers on the problems associated with the excessive use of fertilizers and other chemicals, as well as the irrigation of crops with waste and all sorts of polluted water, and the need to grow crops with safe levels of heavy metals [16].

\section{Pb Phytotoxicity}

$\mathrm{Pb}$ is known to negatively affect some of the most classical endpoints of plant toxicity like seed germination rate, seedling growth, dry mass of roots and shoots, photosynthesis, plant water status, mineral nutrition, and enzymatic activities [53]. In general, effects are more pronounced at higher concentrations and continuance. In some cases, lower concentrations can stimulate metabolic processes and the enzymes involved in those processes [36].

These negative effects can be expressed as symptoms in the form of chlorotic spots, necrotic lesions in leaf surface, senescence of the leaf, and stunted growth. Germination of seeds is drastically affected at higher concentrations. Development and growth of root and shoot in seedling stage are also affected roots being more sensitive.

$\mathrm{Pb}$ negatively influences growth by reducing the uptake and transport of nutrients in plants, such as $\mathrm{Ca}, \mathrm{Fe}, \mathrm{Mg}$, $\mathrm{Mn}, \mathrm{P}$, and $\mathrm{Zn}$, and by blocking the entry or binding of the ions to ion-carriers making them unavailable for uptake and transport from roots to leaves [54]. Thus, $\mathrm{Pb}$ interferes with several physiological and biochemical processes; photosynthesis being one of the most affected [36].
Many European countries have adopted a bioavailability based rationale to improve the reliability of assessments of metal uptake [55]. Current legislation in most countries still uses total soil metal concentration as a simple index of hazard in contaminated soils, even though this approach does not take account of soil characteristics which influence the bioavailability of metallic pollutants in contaminated soil [56].

This has major implications for diet-related risk assessments as these often rely on a generic vegetable approach to predict the transfer of trace elements to the human diet (Section 6).

\section{Metals and Oxidative Stress}

8.1. General Considerations. Reactive oxygen species (ROS) are formed and degraded by all aerobic organisms, leading to either physiological concentrations required for normal cell function or excessive quantities, a state called oxidative stress [57]. Under normal physiological conditions a balance is maintained between the formation of ROS and the cells protective antioxidant mechanism. However, this balance can be disturbed with many environmental stresses including temperature, salinity, drought, flooding, nutritional imbalances and postanoxia stress, a range of gaseous pollutants (ozone, nitrogen oxides, volatile organic compounds, etc.), heavy metals, pathogens attack, and herbicides which have been indicated to increase oxidative stress, leading to overproduction of ROS overcoming the cellular antioxidant capacity $[58,59]$.

These stresses lead to a series of changes in the plant resulting in deficient plant growth and development by affecting molecular, biochemical, morphological, and physiological, processes [59]. The changes caused by various stressful conditions are frequently due to a secondary stress (usually osmotic or oxidative) that perturbs the structural and functional stability of membrane proteins and disrupts cellular homeostasis [60, 61].

ROS are molecules with an unpaired electron making them highly reactive, by interacting nonspecifically with a variety of cellular components [62]. All aerobic organisms are totally dependent upon redox reactions, and the transfer of single electrons and many life processes (e.g., oxidative respiration, photorespiration, photosynthesis, lipid metabolism, and cell signaling) involve free radical intermediates, molecular oxygen, and activated oxygen species such as the superoxide radical anion $\left(\mathrm{O}_{2}{ }^{-}\right)$, the hydroxyl radical $\left(\mathrm{HO}^{\bullet}\right)$, and peroxyl radicals $\left(\mathrm{ROO}^{\bullet}\right)$, as well as nonradical derivatives of molecular oxygen $\left(\mathrm{O}_{2}\right)$, such as hydrogen peroxide $\left(\mathrm{H}_{2} \mathrm{O}_{2}\right)$, hypochlorous acid $(\mathrm{HOCl})$, singlet oxygen $\mathrm{O}_{2}$, and peroxynitrite $\left(\mathrm{ONOO}^{-}\right)$[63-65]. Although $\mathrm{H}_{2} \mathrm{O}_{2}$ per se does not contain any unpaired electrons, it is ascribed to ROS, as it can be easily converted into more aggressive radical species, for example into $\mathrm{HO}^{\bullet}$ via Fentoncatalyzed reduction. Moreover, $\mathrm{H}_{2} \mathrm{O}_{2}$ is membrane permeable and diffusible, proving it suitable for intracellular signaling. Uncontrolled ROS production may ultimately attack macromolecules such as polyunsaturated fatty acids (PUFAs) of the chloroplast membranes, leading to toxic breakdown products and trigger 
lipid peroxidation $[66,67]$. Peroxidation injury of the cell membrane leads to leakage of cellular contents, failure of cell function, rapid desiccation, and, eventually to a breakdown in structural integrity which can lead to necrosis [68].

Scandalios [69] described some damages induced by ROS on biomolecules:

(i) Oxidative damage to lipids occurs via several mechanisms of ROS reacting with fatty acids in the membrane lipid bilayer, leading to membrane leakage and cell death. In foods, lipid peroxidation causes rancidity and development of undesirable odors and flavors.

(ii) In proteins, oxidative damage is due to site-specific amino acids modifications since specific amino acids differ in their susceptibility to ROS attack. Other effects of protein oxidative damage are: fragmentation of the peptide chain, aggregation of crosslinked reaction products, altered electrical charge, increase of susceptibility to proteolysis, oxidation of $\mathrm{Fe}-\mathrm{S}$ centers by $\mathrm{O}_{2}{ }^{\bullet-}$, destroying enzymatic function, oxidation of specific amino "marks" proteins for degradation by specific proteases and oxidation of specific amino acids (e.g., Try) leading to crosslinking.

(iii) DNA damage by ROS leads to DNA deletions, mutations, translocations, base degradation, single-strand breakage, and cross-linking of DNA to proteins.

In plants, ROS are produced within the cellular compartments like chloroplast, mitochondria, cytosol, plasma membrane, microbodies (peroxisomes and glyoxisomes), and in the cell walls during metabolic pathways as photosynthesis and photorespiration, which is the most obvious oxygenation pathways in the chloroplast [70]. The main types of active $\mathrm{O}_{2}$ species are superoxide and $\mathrm{H}_{2} \mathrm{O}_{2}$. In peroxisomes and glyoxisomes, however, just $\mathrm{H}_{2} \mathrm{O}_{2}$ is produced.

Hydrogen peroxide $\left(\mathrm{H}_{2} \mathrm{O}_{2}\right)$ is an interesting form of ROS since it has been considered to be a second messenger for signals generated by ROS due to the capacity to easily diffuse through the membranes and it's relatively long life [70]. Many studies have suggested the existence of a close interaction between intracellular $\mathrm{H}_{2} \mathrm{O}_{2}$ and cytosolic calcium in response to biotic and abiotic stresses. In fact, environmental stress might trigger a rapid and transient increase in calcium influx, which enhances the generation of $\mathrm{H}_{2} \mathrm{O}_{2}$. Yang and Poovaiah [71] and other authors have proposed calcium/calmodulin (CAM) a controlling mechanism of $\mathrm{H}_{2} \mathrm{O}_{2}$ homeostasis in plants. They also verified that increasing cytosolic $\mathrm{Ca}^{2+}$ can downregulate $\mathrm{H}_{2} \mathrm{O}_{2}$ levels by means of $\mathrm{Ca}^{2+} / \mathrm{CaM}$-mediated stimulation of catalase activity in tobacco leaves.

The characterization and monitorization of the oxidative stress can be assessed by many parameters: plant membranes integrity evaluation, lipid peroxidation estimation through thiobarbituric acid reactive substances, measurement of redox potential and stress-related metabolites $\left(\mathrm{H}_{2} \mathrm{O}_{2}\right.$, ascorbic acid, and glutathione), enzymes like poly (ADP-ribose)-polymerase, screening for heat-shock proteins (HSP), enzymes associated with cell cycle,and evaluation of antioxidant enzymes [72]. According with Wang et al. [73], biological monitoring is a direct test of biological responses to environmental contaminants and has been proposed to complement the information given by chemical analysis. Thus, the use of biochemical or physiological parameters as biomarkers of ecotoxicity is under constant development and has the advantage of delineating effects before observed symptom.

Several techniques can be applied to assess ROS-induced DNA/chromosome injuries such as, flow cytometry (measurement of changes in chromosome number and DNA content), microdensitometry, and fluorescent in situ hybridization (FISH) (look for somatic recombination) or others that detect DNA sequence mutations such as microsatellites, restriction fragment length (RFLP), and amplified fragment length polymorphism (AFLP) [72].

Plants respond in different ways to heavy metal ion stress including exclusion, chelation, compartmentalization, and expression of stress protein genes. This way, being $\mathrm{Pb}$ one of the main sources of environmental pollution, previous studies have shown that $\mathrm{Pb}$ inhibits metabolic processes such as nitrogen assimilation, photosynthesis, respiration, water uptake, and transcription. In fact, $\mathrm{Pb}$ causes two types of unfavorable processes in biological systems. Firstly, $\mathrm{Pb}$ inactivates several enzymes by binding with their $\mathrm{SH}$ groups. Secondly, $\mathrm{Pb}$ ions can lead to oxidative stress by intensifying the processes of reactive oxygen species (ROS) production. These processes are mutually connected and stimulate each other by destructively affecting cell structure and metabolism, resulting in a possible decreased efficiency of oxidation-reduction enzymes or the electron transport system leading to fast production of ROS in the cell. $\mathrm{Pb}$ can exert a negative effect on mitochondria by decreasing the number of mitochondrial cristae, which in turn can lower the capacity of oxidative phosphorylation during photosynthesis and respiration [74].

\section{Plant Protection Mechanisms against Oxidative Stress: Antioxidant Defense System}

Plants have different defense strategies to cope with the toxicity of heavy metals. The primary defense strategy consists in avoiding the metal entry into the cell by excluding or binding it to a cell wall. The secondary defense system is composed of various antioxidants to combat the increased production of ROS caused by metals [45].

These antioxidants are substances that (either directly or indirectly) protect cells against adverse effects of xenobiotics, drugs, carcinogens, and toxic radical reactions.

In plant cells, the antioxidant defense system is essentially constituted by superoxide dismutase (SOD), catalase (CAT), ascorbate peroxidase (APX), glutathione (GSH), ascorbate (vitamin $\mathrm{C}$ ), tocopherol (vitamin E), and carotenoids among others. These species are distributed through the cell and are present in vacuoles and chloroplasts in higher amounts.

The following distribution for the main antioxidant components was suggested by Scandalios [69]: 73\% in the vacuole (ascorbate, glutathione, and peroxidase); 17\% in 
chloroplasts (carotenoids, $\alpha$-tocopherol, ascorbate, ascorbate peroxidase, glutathione, glutathione reductase, $\mathrm{Cu} / \mathrm{Zn}$ SOD, monodehydroascorbate radical reductase, and dehydroascorbate reductase); $5 \%$ in the cytosol (ascorbate peroxidase, CuZn-SOD, catalase, peroxidase, glutathione, ascorbate, glutathione reductase, and monodehydroascorbate radical reductase); $4 \%$ in the apoplast (peroxidase and ascorbate); $1 \%$ in the mitochondria (catalase, glutathione, glutathione reductase, Mn-SOD, and monodehydroascorbate radical reductase) and peroxisomes (catalase; $\mathrm{Cu} / \mathrm{Zn}-\mathrm{SOD}$ ).

Besides the antioxidative system, stress proteins (also called heat-shock proteins, HSPs) are also activated in plant species under adverse conditions [73], and the accumulation of some organic compounds in plants such as polyamines (diamine, putrescine, triamine spermidine, and tetramine spermin) and L-proline play significant roles in plant adaptation to a variety of environmental stresses $[75,76]$.

Clearly, plant response to $\mathrm{Pb}$ contamination is a key research problem, and a special effort is being undertaken in seeking factors affecting the reduction of $\mathrm{Pb}$ absorption or toxicity in plants [74].

Selenium (Se) is one of the potential antagonists to $\mathrm{Pb}$. Recent publications indicate that Se addition may also alter the total content of heavy metals in animal tissues by reducing their uptake by plants [77-81]. Magdalena MroczekZdyrska and Wójcik [74] showed that cell viability was enhanced at low concentrations whereas at high concentrations Se was pro-oxidant and increased the lipid peroxidation and cell membrane injury. On the other hand, addition of Se controlled the accumulation of $\mathrm{Pb}$ and $\mathrm{Cd}$ in lettuce and enhanced absorption of some nutritional elements (Fe, Mn, $\mathrm{Cu}, \mathrm{Ca}$, and $\mathrm{Mg}$ ) [77].

Rossato et al. [45] discussed that $\mathrm{Pb}$ stress triggered an efficient defense mechanism against oxidative stress in Pluchea sagittalis, but its magnitude was depending on the plant organ and of their physiological status.

\section{Phytoremediation}

10.1. General Considerations. Heavy metals, with soil residence times of thousands of years, pose numerous health dangers to higher organisms. They are known to affect plant growth, ground cover and to have a negative impact on soil microflora. It is well known that heavy metals cannot be chemically degraded and need to be physically removed or transformed into nontoxic compounds [24].

The generic term "phytoremediation" consists of the Greek prefix phyto (plant), attached to the Latin root remedium (to correct or remove an evil) $[82,83]$. Generally, according to Erakhrumen and Agbontalor [82], phytoremediation is defined as an emerging technology using selected plants to clean up the contaminated environment from hazardous contaminants to improve the environment quality [24].

The uptake mechanisms through phytoremediation technology are divided between organic and inorganic contaminants. For organics, it involves phytostabilization, rhizodegradation, rhizofiltration, phytodegradation, and phytovolatilization. For inorganics, mechanisms involved are phytostabilization, rhizofiltration, phytoaccumulation, and phytovolatilization [24].

Plants have developed highly specific and very efficient mechanisms to obtain essential micronutrients from the environment, even when these are present at low ppm levels. Plant roots, are able to solubilize and take up micronutrients from very low levels in the soil, even from nearly insoluble precipitates. Plants have also developed highly specific mechanisms to translocate and store micronutrients. The same mechanisms are also involved in the uptake, translocation, and storage of toxic elements, whose chemical properties simulate those of essential elements. Thus, micronutrient uptake mechanisms are of great interest to phytoremediation [84].

Metal accumulating plant species can concentrate heavy metals like $\mathrm{Cd}, \mathrm{Zn}, \mathrm{Co}, \mathrm{Mn}, \mathrm{Ni}$, and $\mathrm{Pb}$ up to 100 or 1000 times more than those taken up by nonaccumulator (excluder) plants. In most cases, bacteria and fungi living in the rhizosphere closely associated with plants may contribute to mobilize metal ions, increasing the bioavailable fraction [24].

There are several factors affecting the uptake mechanisms like: plant species characteristic, properties of medium agronomical practices developed to enhance remediation ( $\mathrm{pH}$ adjustment, addition of chelators, and fertilizers), and addition of chelating agent [24].

\section{Phytoremediation Advantages and Limitations}

Phytoremediation has several advantages but remains controversial in some aspects. We will describe below some of the main advantages and limitations of this strategy applied to metals (e.g., $\mathrm{Pb}$ ).

Advantages can be: low cost (is lower than traditional processes); applicablity for a wide range of contaminants; effective in contaminant reduction; environmental friendly method and less disruptive than current techniques of physical and chemical processes (e.g., metal precipitation or otherwise attached to an insoluble form through adsorption or ion exchange [85]; solidification and stabilization are other possibilities [86]); plants can be easily monitored; possibility of recovery and reuse of valuable metals (by companies specializing in "phytomining"); aesthetically pleasing.

Limitations of phytoremediation technology are: surface area and depth occupied by the roots; slow growth and low biomass production require a long-term commitment-it is a time-consuming method; the age of plant; the survival of the plants is affected by the toxicity of the contaminated land and the general soil condition; climatic condition; soil chemistry; the contaminant concentration; bioaccumulation of contaminants, especially metals, into the plants which, then, pass them into the food chain from primary level consumers upwards or requires the safe disposal of the affected plant material; the impacts of contaminated vegetationwith plant-based systems of remediation, it is not possible to completely prevent the leakage of contaminants into the groundwater (without the complete removal of the contaminated ground, which in itself does not resolve the problem of contamination) [24]. 
Heavy metals uptake, by plants using phytoremediation technology, seems to be a prosperous way to remediate heavy-metals-contaminated environment. In fact it has some advantages compared with other commonly used conventional technologies. However, several factors must be considered in order to accomplish a high performance of remediation result being the most important factor a suitable plant species which can be used to uptake the contaminant. Even if the phytoremediation technique seems to be one of the best alternatives, it also has some limitations. Further research is needed.

\section{Nanotechnology Applications in Plant Science}

Nanomaterials and nanotechnology have been widely applied all over the world in this last decade [87].

Despite nanotechnology being mainly focused on animal science and medical research (in regard of biological applications), nanotechnology can also be applied to plant science research in order to analyze plant genomics and gene function as well as improvement of crop species [87]. However, in 1996, USEPA (United States Environmental Protection Agency) evidenced several negative effects of nanoparticles (NSPs) on growth and development of plantlets.

More recently, some phytotoxicity studies applied in higher plants, using nanoparticles, have been developed. Some examples are given as follows: improvement of the level of seed germination and root growth; increase of source of iron (or other micronutrients); enhancement of Rubisco carboxilase activity; effect on growth of specific species. The species that have been studied are Raphanus sativus, Brassica napus, Lolium multiflorum, Lactuca sativa, Cucumis sativus, Lolium perenne (using $\mathrm{ZnO}$ nanoparticles), Zea mays (magnetic nanoparticles), Spinacia olerace $\left(\mathrm{TiO}_{2}\right.$ nanoparticles), and Phaseolus vulgaris (nano alumin particules), Triticum aestivum ( $\mathrm{Cu}$ nanoparticles) among others [88-91]. In order to understand the possible benefits of applying nanotechnology to agriculture, the first step should be to analyze the level of penetration and transport of nanoparticles in plants. It is established that these particles tagged to agrochemicals or to other substances could reduce the injury to plant tissues and the amount of chemicals released into the environment. Some contact is however inescapable, due to the strong interaction of plants with soil growth substrates [87].

Deposition of atmospheric particulate matter on the leaves leads to remarkable alteration in the transpiration rates, thermal balance, and photosynthesis. Da Silva et al. [92] showed that nanoparticles may enter leaf surface.

Since nanoparticles are introduced into the soil as a result of human activities, among the many fields that nanotechnology takes into consideration, it is also important to recall the interactions between nanoparticles, plants, and soil. There are many gaps in our knowledge on the ecotoxicity of NSPs and there are many unresolved problems and new challenges concerning the biological effects of these NSPs [87].

The elements for acceptable catalytic metal nanoparticles have been restricted to groups VIII and IB of the periodic table, especially palladium, platinum $(\mathrm{Pt})$, silver, and $\mathrm{Au}$
[93]. The majority of studies involving $\mathrm{Pb}$ nanoparticles were driven to electrochemical materials such as exploration of electrically conductive adhesives (ECAs) for surface mount technology and flip chip applications as $\mathrm{Pb}$-free alternatives [94]. fabrication of pure $\mathrm{Pb}$ nanoparticles with nonoxidized surfaces due to $\mathrm{Pb}$ particles being readily oxidized even at ambient temperature and in high vacuum [93]; Synthesis of lead dioxide nanoparticles by pulsed current electrochemical method to use as the cathode of lead-acid batteries [95].

\section{References}

[1] M. M. Lasat, "Phytoextraction of metals from contaminated soil: a review of plant/soil/metal interaction and assessment of pertinent agronomic issues," Journal of Hazardous Substance Research, vol. 2, no. 5, pp. 1-25, 2000.

[2] D. I. Arnon and P. R. Stout, "The essentially of certain elements in minute quantity for plants with special reference to copper," Plant Physiology, vol. 14, no. 2, pp. 371-375, 1939.

[3] A. Gomez, The nanoparticle formation and uptake of precious metals by living alfalfa plants [M.S. thesis], University of Texas at El Paso, 2002.

[4] L. Taiz and E. Zeiger, Plant Physiology, Sinauer, Sunderland, Mass, USA, 2nd edition, 1998.

[5] F. Ghanati, A. Morita, and H. Yokota, "Effects of aluminum on the growth of tea plant and activation of antioxidant system," Plant and Soil, vol. 276, no. 1-2, pp. 133-141, 2005.

[6] J. R. Peralta-Videa, M. L. Lopez, M. Narayan, G. Saupe, and J. Gardea-Torresdey, "The biochemistry of environmental heavy metal uptake by plants: implications for the food chain," International Journal of Biochemistry and Cell Biology, vol. 41, no. 8-9, pp. 1665-1677, 2009.

[7] F. M. Johnson, "The genetic effects of environmental lead," Mutation Research, vol. 410, no. 2, pp. 123-140, 1998.

[8] T. Rehren, "A review of factors affecting the composition of early Egyptian glasses and faience: alkali and alkali earth oxides," Journal of Archaeological Science, vol. 35, no. 5, pp. 1345-1354, 2008.

[9] F. Retief and L. P. Cilliers, "Lead poisoning in ancient Rome," Acta Theologica Suplemmentum, vol. 7, 2005.

[10] R. D. Prengaman, "The impact of the new $36 \mathrm{~V}$ lead-acid battery systems on lead consumption," Journal of Power Sources, vol. 116, no. 1-2, pp. 14-22, 2003.

[11] N. Vural and Y. Duydu, "Biological monitoring of lead in workers exposed to tetraethyllead," Science of the Total Environment, vol. 171, no. 1-3, pp. 183-187, 1995.

[12] H. Roberts, "Changing patterns in global lead supply and demand," Journal of Power Sources, vol. 116, no. 1-2, pp. 23-31, 2003.

[13] D. Smith, "Lead market: outlook for the global market and prices," Journal of Power Sources, vol. 78, no. 1, pp. 188-192, 1999.

[14] USGS (United States Geological Survey), "Mineral Commodity Summary," January 2011.

[15] R. K. Rattan, S. P. Datta, and A. K. Singh, "Effect of long term application of sewage effluents on available water status in soils under Keshopure Effluent Irrigation Scheme in Delhi," Journal of Water Management, no. 9, pp. 21-26, 2001.

[16] E. I. Uwah, N. P. Ndahi, F. I. Abdulrahman, and V. O. Ogugbuaja, "Heavy metal levels in spinach (Amaranthus caudatus) and lettuce (Lactuca sativa) grown in Maiduguri, Nigeria," Journal of Environmental Chemistry and Ecotoxicology, vol. 3, no. 10, pp. 264-271, 2011. 
[17] G. Nabulo, Assessing risks to human health from peri-urban agriculture in Uganda [Ph.D. thesis], University of Nottingham, 2009.

[18] Y. B. Ho and K. M. Tai, "Elevated levels of lead and other metals in roadside soil and grass and their use to monitor aerial metal depositions in Hong Kong," Environmental Pollution, vol. 49, no. 1, pp. 37-51, 1988.

[19] R. Garcia and E. Millán, "Assessment of $\mathrm{Cd}, \mathrm{Pb}$ and $\mathrm{Zn}$ contamination in roadside soils and grasses from Gipuzkoa (Spain)," Chemosphere, vol. 37, no. 8, pp. 1615-1625, 1998.

[20] G. Nabulo, C. R. Black, and S. D. Young, "Trace metal uptake by tropical vegetables grown on soil amended with urban sewage sludge," Environmental Pollution, vol. 159, no. 2, pp. 368-376, 2011.

[21] Z.-T. Xiong, "Lead uptake and effects on seed germination and plant growth in a $\mathrm{Pb}$ hyperaccumulator Brassica pekinensis Rupr," Bulletin of Environmental Contamination and Toxicology, vol. 60, no. 2, pp. 285-291, 1998.

[22] E. I. Uwah, "Concentration levels of some heavy metal pollutants in soil, and carrot (Daucus carota) obtained in Maiduguri, Nigeria," Continental Journal of Applied Sciences, vol. 4, pp. 76-88, 2009.

[23] O. C. Othman, "Heavy metals in green vegetables and soils from vegetable gardens in Dar Es Salaam, Tanzania," Tanzania Journal of Science, no. 27, pp. 37-48, 2001.

[24] B. V. Tangahu, S. R. S. Abdullah, H. Basri, M. Idris, N. Anuar, and M. Mukhlisin, "A review on heavy metals (As, $\mathrm{Pb}$, and $\mathrm{Hg}$ ) uptake by plants through phytoremediation," International Journal of Chemical Engineering Pages, 31 pages, 2011.

[25] G. De La Rosa, J. R. Peralta-Videa, M. Montes, J. G. Parsons, I. Cano-Aguilera, and J. L. Gardea-Torresdey, "Cadmium uptake and translocation in tumbleweed (Salsola kali), a potential Cd-hyperaccumulator desert plant species: ICP/OES and XAS studies," Chemosphere, vol. 55, no. 9, pp. 1159-1168, 2004.

[26] J. L. Morel, M. Mench, and A. Guckert, "Measurement of $\mathrm{Pb}^{2+}$, $\mathrm{Cu}^{2+}$ and $\mathrm{Cd}^{2+}$ binding with mucilage exudates from maize (Zea mays L.) roots," Biology and Fertility of Soils, vol. 2, no. 1, pp. 29-34, 1986.

[27] P. Sharma and R. S. Dubey, "Lead toxicity in plants," Brazilian Journal of Plant Physiology, vol. 17, no. 1, pp. 35-52, 2005.

[28] M. Wierzbicka, "Comparison of lead tolerance in Allium cepa with other plant species," Environmental Pollution, vol. 104, no. 1, pp. 41-52, 1999.

[29] M. J. Blaylock and J. W. Huang, "Phytoextraction of metals," in PhyToremediation of Toxic Metals: Using Plants To Clean Up the Environment, I. Raskin and B. D. Ensley, Eds., pp. 53-71, John Wiley \& Sons, New York, NY, USA, 2000.

[30] P. D. Alexander, B. J. Alloway, and A. M. Dourado, "Genotypic variations in the accumulation of $\mathrm{Cd}, \mathrm{Cu}, \mathrm{Pb}$ and $\mathrm{Zn}$ exhibited by six commonly grown vegetables," Environmental Pollution, vol. 144, no. 3, pp. 736-745, 2006.

[31] A. Hanć, D. Baralłkiewicz, A. Piechalaka, B. Tomaszewska, B. Wagner, and E. Bulska, "An analysis of long-distance root to leaf transport of lead in pisum sativum plants by laser ablation-ICP-MS," International Journal of Environmental Analytical Chemistry, vol. 89, no. 8-12, pp. 651-659, 2009.

[32] S. O. Eun, H. S. Youn, and Y. Lee, "Lead disturbs microtubule organization in the root meristem of Zea mays," Physiologia Plantarum, vol. 110, no. 3, pp. 357-365, 2000.

[33] L. E. Kerper and P. M. Hinkle, "Cellular uptake of lead is activated by depletion of intracellular calcium stores," Journal of Biological Chemistry, vol. 272, no. 13, pp. 8346-8352, 1997.

[34] T. Arazi, R. Sunkar, B. Kaplan, and H. Fromm, "A tobacco plasma membrane calmodulin-binding transporter confers
$\mathrm{Ni}^{2+}$ tolerance and $\mathrm{Pb}^{2+}$ hypersensitivity in transgenic plants," Plant Journal, vol. 20, no. 2, pp. 171-182, 1999.

[35] S. V. Sahi, N. L. Bryant, N. C. Sharma, and S. R. Singh, "Characterization of a lead hyperaccumulator shrub, Sesbania drummondii," Environmental Science and Technology, vol. 36, no. 21, pp. 4676-4680, 2002.

[36] E. Gomes, Genotoxicity and cytotoxicity of $\mathrm{Cr}$ (VI) and $\mathrm{Pb}^{2+}$ in pisum sativum [Ph.D. thesis], University of Aveiro, Aveiro, Portugal, 2011.

[37] I. V. Seregin, L. K. Shpigun, and V. B. Ivanov, "Distribution and toxic effects of cadmium and lead on maize roots," Russian Journal of Plant Physiology, vol. 51, no. 4, pp. 525-533, 2004.

[38] A. Varga, G. Záray, F. Fodor, and E. Cseh, "Study of interaction of iron and lead during their uptake process in wheat roots by total-reflection X-ray fluorescence spectrometry," Spectrochimica Acta B, vol. 52, no. 7, pp. 1027-1032, 1997.

[39] M. Marmiroli, G. Antonioli, E. Maestri, and N. Marmiroli, "Evidence of the involvement of plant ligno-cellulosic structure in the sequestration of $\mathrm{Pb}$ : an X-ray spectroscopy-based analysis," Environmental Pollution, vol. 134, no. 2, pp. 217-227, 2005.

[40] C. S. Cobbett, "Phytochelatins and their roles in heavy metal detoxi," Current Opinion in Plant Biology, vol. 123, no. 3, pp. 211-216, 2000.

[41] N. C. Sharma, J. L. Gardea-Torresdey, J. Parsons, and S. V. Sahi, "Chemical speciation and cellular deposition of lead in Sesbania drummondii," Environmental Toxicology and Chemistry, vol. 23, no. 9, pp. 2068-2073, 2004.

[42] M. L. López, J. R. Peralta-Videa, J. G. Parsons, T. Benitez, and J. L. Gardea-Torresdey, "Gibberellic acid, kinetin, and the mixture indole-3-acetic acid-kinetin assisted with EDTAinduced lead hyperaccumulation in alfalfa plants," Environmental Science and Technology, vol. 41, no. 23, pp. 8165-8170, 2007.

[43] M. L. López, J. R. Peralta-Videa, J. G. Parsons, J. L. GardeaTorresdey, and M. Duarte-Gardea, "Effect of indole-3-acetic acid, kinetin, and ethylenediaminetetraacetic acid on plant growth and uptake and translocation of lead, micronutrients, and macronutrients in alfalfa plants," International Journal of Phytoremediation, vol. 11, no. 2, pp. 131-149, 2009.

[44] W.-C. Ma, "Lead in mammals," in Environmental Contaminants in Wildlife, W. N. Beyer, G. Heinz, and A. W. RedmonNorwood, Eds., SETAC Special Publication Series, pp. 281296, CRC Lewis, Boca Raton, Fla, USA, 1996.

[45] L. V. Rossato, F. T. Nicoloso, J. G. Farias et al., "Effects of lead on the growth, lead accumulation and physiological responses of Pluchea sagittalis," Ecotoxicology, vol. 21, pp. 111-123, 2012.

[46] P. Zhuang, H. Zou, and W. Shu, "Biotransfer of heavy metals along a soil-plant-insect-chicken food chain: field study," Journal of Environmental Sciences, vol. 21, no. 6, pp. 849-853, 2009.

[47] D. R. Smith, M. W. Kahng, B. Quintanilla-Vega, and B. A. Fowler, "High-affinity renal lead-binding proteins in environmentally-exposed humans," Chemico-Biological Interactions, vol. 115, no. 1, pp. 39-52, 1998.

[48] ATSDR, "Toxicological profile for lead," 2007, http://www .atsdr.cdc.gov/.

[49] K. J. I. Nirmal, S. Hiren, and N. K. Rita, "Characterization of heavy metals in vegetables using Inductive Coupled Plasma Analyzer (ICPA)," Journal of Applied Sciences and Environmental Management, vol. 11, no. 3, pp. 75-79, 2007.

[50] J. Xu and I. Thornton, "Arsenic in garden soils and vegetable crops in Cornwall, England: implications for human health," 
Environmental Geochemistry and Health, vol. 7, no. 4, pp. 131133, 1985.

[51] D. Y. Boon and P. N. Soltanpour, "Lead, cadmium, and zinc contamination of Aspen garden soils and vegetation," Journal of Environmental Quality, vol. 21, no. 1, pp. 82-86, 1992.

[52] K. R. Mahaffey, S. G. Capar, B. C. Gladen, and B. A. Fowler, "Concurrent exposure to lead, cadmium, and arsenic. Effects on toxicity and tissue metal concentrations in the rat," Journal of Laboratory and Clinical Medicine, vol. 98, no. 4, pp. 463-481, 1981.

[53] O. Munzuroglu and H. Geckil, "Effects of metals on seed germination, root elongation, and coleoptile and hypocotyl growth in Triticum aestivum and Cucumis sativus," Archives of Environmental Contamination and Toxicology, vol. 43, no. 2, pp. 203-213, 2002.

[54] Z.-T. Xiong, "Bioaccumulation and physiological effects of excess lead in a roadside pioneer species Sonchus oleraceus L.," Environmental Pollution, vol. 97, no. 3, pp. 275-279, 1997.

[55] A. Prueb, "Action values for mobile $\left(\mathrm{NH}_{4} \mathrm{NO}_{3}\right)$ trace elements in soils based on the German national standard DIN, 19730," in Contaminated Soils. Proceedings of 3rd International Conference on the Biogeochemistry of Trace Elements, R. Prost, Ed., pp. 415-423, INRA, Paris, France, 1997.

[56] S. P. Datta and S. D. Young, "Predicting metal uptake and risk to the human food chain from leaf vegetables grown on soils amended by long-term application of sewage sludge," Water, Air, and Soil Pollution, vol. 163, no. 1-4, pp. 119-136, 2005.

[57] J. Nordberg and E. S. J. Arnér, "Reactive oxygen species, antioxidants, and the mammalian thioredoxin system," Free Radical Biology and Medicine, vol. 31, no. 11, pp. 1287-1312, 2001.

[58] B. Vinocur and A. Altman, "Recent advances in engineering plant tolerance to abiotic stress: achievements and limitations," Current Opinion in Biotechnology, vol. 16, no. 2, pp. 123-132, 2005.

[59] W. Wang, B. Vinocur, and A. Altman, "Plant responses to drought, salinity and extreme temperatures: towards genetic engineering for stress tolerance," Planta, vol. 218, no. 1, pp. $1-14,2003$.

[60] K. Shinozaki and K. Yamaguchi-Shinozaki, "Molecular responses to dehydration and low temperature: differences and cross-talk between two stress signaling pathways," Current Opinion in Plant Biology, vol. 3, no. 3, pp. 217-223, 2000.

[61] J. K. Zhu, "Plant salt tolerance," Trends in Plant Science, vol. 6, no. 2, pp. 66-71, 2001.

[62] M. Ashraf, "Biotechnological approach of improving plant salt tolerance using antioxidants as markers," Biotechnology Advances, vol. 27, no. 1, pp. 84-93, 2009.

[63] I. Fridovich, "Fundamental aspects of reactive oxygen species, or what's the matter with oxygen?" Annals of the New York Academy of Sciences, vol. 893, pp. 13-18, 1999.

[64] D. J. Betteridge, "What is oxidative stress?" Metabolism, vol. 49, no. 2, pp. 3-8, 2000.

[65] P. Jezek and L. Hlavata, "Mitochondria in homeostasis of reactive oxygen species in cell, tissues, and organism," International Journal of Biochemistry \& Cell Biology, vol. 37, pp. 2478-2503, 2005.

[66] E. E. Benson, "Do free radicals have a role in plant tissue culture recalcitrance?" In Vitro Cellular and Developmental Biology, vol. 36, no. 3, pp. 163-170, 2000.

[67] H. K. Ledford and K. K. Niyogi, "Singlet oxygen and photooxidative stress management in plants and algae," Plant, Cell and Environment, vol. 28, no. 8, pp. 1037-1045, 2005.
[68] J. G. Scandalios, "Oxygen stress and superoxide dismutases," Plant Physiology, vol. 101, no. 1, pp. 7-12, 1993.

[69] J. G. Scandalios, "Oxidative stress: molecular perception and transduction of signals triggering antioxidant gene defenses," Brazilian Journal of Medical and Biological Research, vol. 38, no. 7, pp. 995-1014, 2005.

[70] A. Arora, R. K. Sairam, and G. C. Srivastava, "Oxidative stress and antioxidative system in plants," Current Science, vol. 82, no. 10, pp. 1227-1238, 2002.

[71] T. Yang and B. W. Poovaiah, "Hydrogen peroxide homeostasis: activation of plant catalase by calcium/calmodulin," Proceedings of the National Academy of Sciences of the United States of America, vol. 99, no. 6, pp. 4097-4102, 2002.

[72] A. C. Cassells and R. F. Curry, "Oxidative stress and physiological, epigenetic and genetic variability in plant tissue culture: implications for micropropagators and genetic engineers," Plant Cell, Tissue and Organ Culture, vol. 64, no. 2-3, pp. 145157, 2001.

[73] C. Wang, X. Gu, X. Wang et al., "Stress response and potential biomarkers in spinach (Spinacia oleracea L.) seedlings exposed to soil lead," Ecotoxicology and Environmental Safety, vol. 74, no. 1, pp. 41-47, 2011.

[74] M. Mroczek-Zdyrska and M. Wójcik, "The influence of selenium on root growth and oxidativestress induced by lead in vicia faba L. minor plants," Biological Trace Element Research, vol. 147, no. 1-3, pp. 320-328, 2012.

[75] G. P. Wei, L. F. Yang, Y. L. Zhu, and G. Chen, "Changes in oxidative damage, antioxidant enzyme activities and polyamine contents in leaves of grafted and non-grafted eggplant seedlings under stress by excess of calcium nitrate," Scientia Horticulturae, vol. 120, no. 4, pp. 443-451, 2009.

[76] O. Tatar and M. N. Gevrek, "Influence of water stress on proline accumulation, lipid peroxidation and water content of wheat," Asian Journal of Plant Sciences, vol. 7, no. 4, pp. 409412, 2008.

[77] P. P. He, X. Z. Lv, and G. Y. Wang, "Effects of Se and Zn supplementation on the antagonism against $\mathrm{Pb}$ and $\mathrm{Cd}$ in vegetables," Environment International, vol. 30, no. 2, pp. 167172, 2004.

[78] A. Fargašová, J. Pastierová, and K. Svetková, "Effect of Semetal pair combinations $(\mathrm{Cd}, \mathrm{Zn}, \mathrm{Cu}, \mathrm{Pb})$ on photosynthetic pigments production and metal accumulation in Sinapis alba L. seedlings," Plant, Soil and Environment, vol. 52, no. 1, pp. 8-15, 2006.

[79] Z. Pedrero, Y. Madrid, H. Hartikainen, and C. Cámara, "Protective effect of selenium in broccoli (Brassica oleracea) plants subjected to cadmium exposure," Journal of Agricultural and Food Chemistry, vol. 56, no. 1, pp. 266-271, 2008.

[80] R. Feng, C. Wei, S. Tu, and X. Sun, "Interactive effects of selenium and arsenic on their uptake by Pteris vittata L. under hydroponic conditions," Environmental and Experimental Botany, vol. 65, no. 2-3, pp. 363-368, 2009.

[81] M. Filek, R. Keskinen, H. Hartikainen et al., "The protective role of selenium in rape seedlings subjected to cadmium stress," Journal of Plant Physiology, vol. 165, no. 8, pp. 833-844, 2008.

[82] A. Erakhrumen and A. Agbontalor, "Review phytoremediation: an environmentally sound technology for pollution prevention, control and remediation in developing countries," Educational Research and Review, vol. 2, no. 7, pp. 151-156, 2007.

[83] U.S. Environmental Protection Agency, "Introduction to Phytoremediation," National Risk Management Research 
Laboratory, EPA/600/R-99/107, 2000, http://www.clu-in.org/ download/remed/introphyto.pdf.

[84] U.S. Department of Energy, "Plume Focus Area, December. Mechanisms of plant uptake, translocation, and storage of toxic elements," Summary Report of a workshop on phytoremediation research needs, 1994, http://www.osti.gov/.

[85] T. Maruyama, S. A. Hannah, and J. M. Cohen, "Metal removal by physical and chemical treatment processes," Journal of the Water Pollution Control Federation, vol. 47, no. 5, pp. 962-975, 1975.

[86] M. Korać, Ž. Kamberović, and B. Tomović, "Treatment of heavy metals contaminated solid wastes-Stabilization," in Proceedings of European Metallurgical Conference (EMC '07), 2007.

[87] R. C. Monica and R. Cremonini, "Nanoparticles and higher plants," Caryologia, vol. 62, no. 2, pp. 161-165, 2009.

[88] D. Lin and B. Xing, "Phytotoxicity of nanoparticles: inhibition of seed germination and root growth," Environmental Pollution, vol. 150, no. 2, pp. 243-250, 2007.

[89] M. Racuciu and D. E. Creanga, "TMA-OH coated magnetic nanoparticles internalized in vegetal tissues," Romanian Journal of Physics, vol. 52, pp. 395-402, 2007.

[90] F. Gao, F. Hong, C. Liu et al., "Mechanism of nanoanatase $\mathrm{TiO}_{2}$ on promoting photosynthetic carbon reaction of spinach: inducing complex of Rubisco-Rubisco activase," Biological Trace Element Research, vol. 111, no. 1-3, pp. 239253, 2006.

[91] R. Doshi, W. Braida, C. Christodoulatos, M. Wazne, and G. O'Connor, "Nano-aluminum: transport through sand columns and environmental effects on plants and soil communities," Environmental Research, vol. 106, no. 3, pp. 296-303, 2008.

[92] L. C. Da Silva, M. A. Oliva, A. A. Azevedo, and J. M. D. Araújo, "Responses of restinga plant species to pollution from an iron pelletization factory," Water, Air, and Soil Pollution, vol. 175, no. 1-4, pp. 241-256, 2006.

[93] J. Kano, T. Kizuka, F. Shikanai, and S. Kojima, "Pure lead nanoparticles with stable metallic surfaces, on perovskite lead strontium titanate particles," Nanotechnology, vol. 20, no. 29, Article ID 295704, 2009.

[94] H. Jiang, K. S. Moon, and C. P. Wong, "Synthesis of Ag-Cu alloy nanoparticles for lead-free interconnect materials," in Proceedings of the 10th International Symposium on Advanced Packaging Materials: Processes, Properties and Interfaces, pp. 173-177, March 2005.

[95] H. Karami and M. Alipour, "Synthesis of lead dioxide nanoparticles by the pulsed current electrochemical method," International Journal of Electrochemical Science, vol. 4, no. 11, pp. 1511-1527, 2009. 

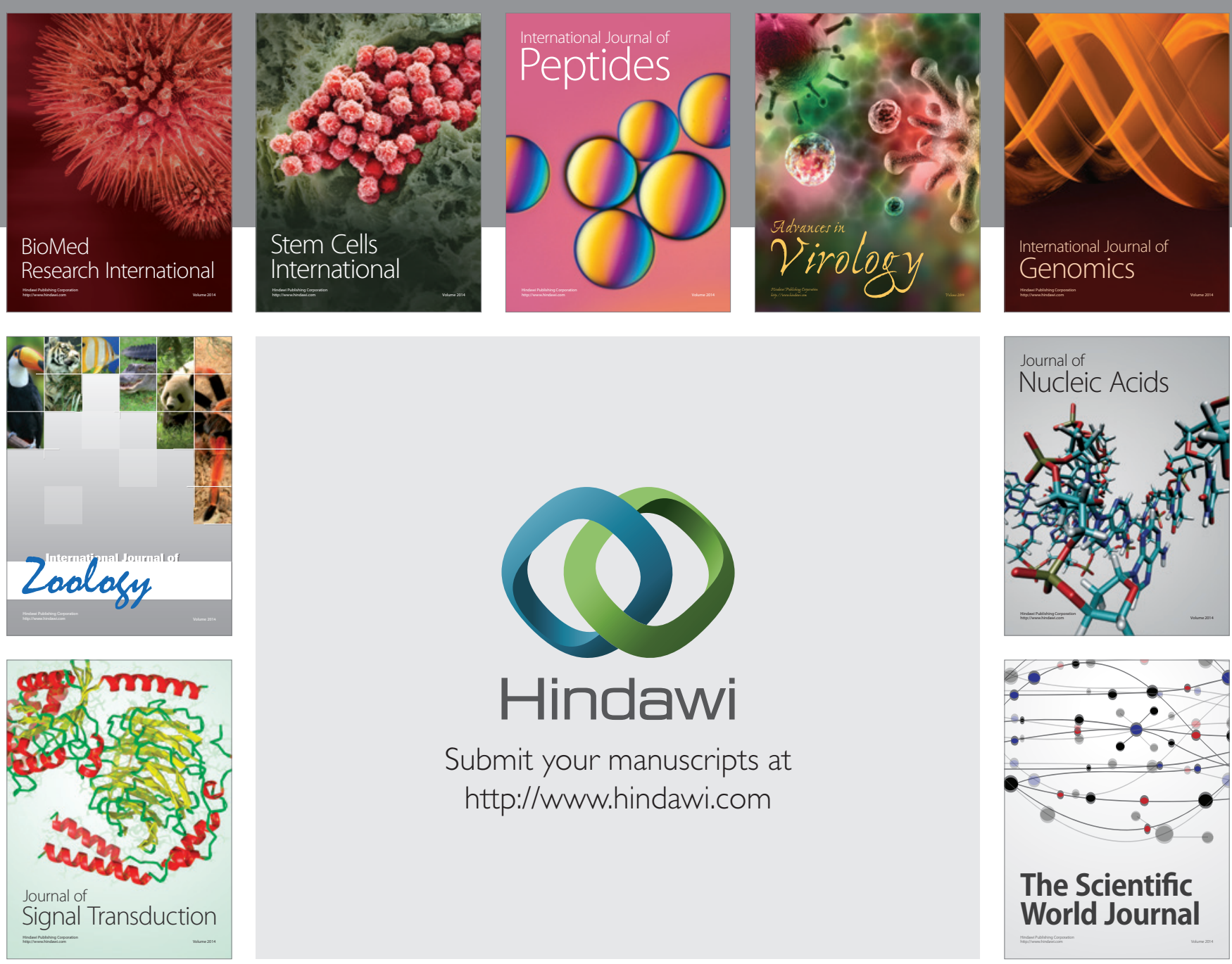

Submit your manuscripts at

http://www.hindawi.com
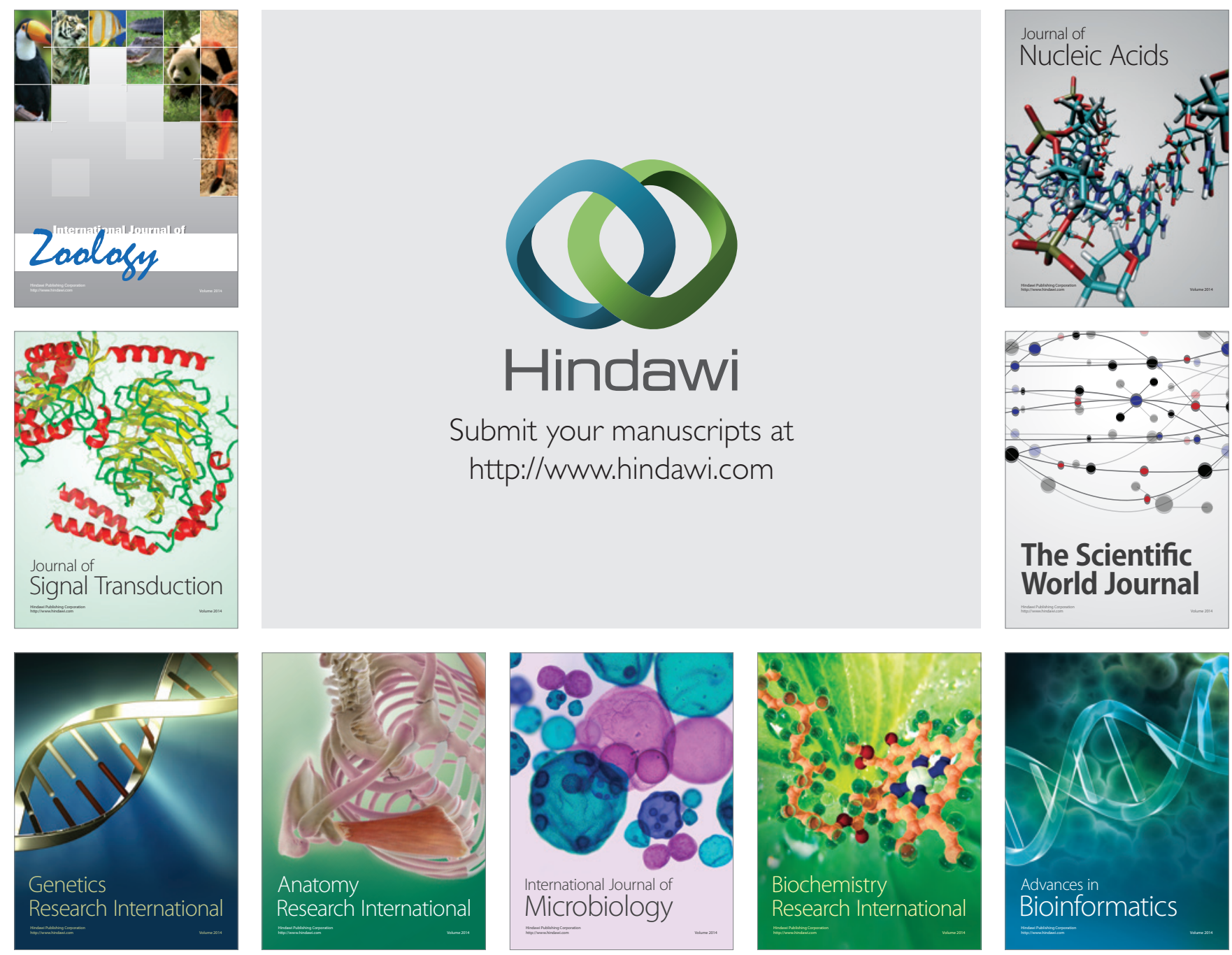

The Scientific World Journal
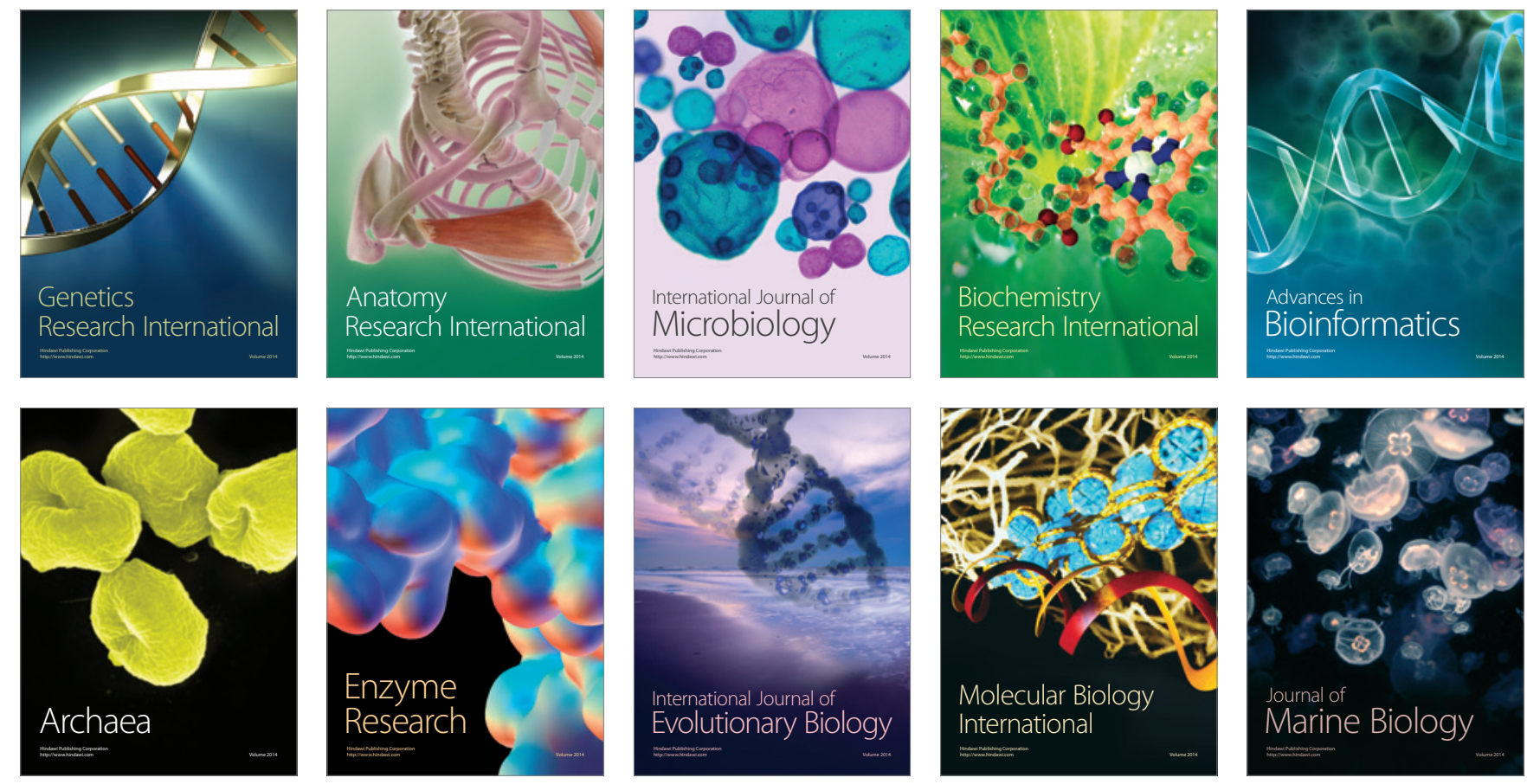